\title{
Into Melville's Intellectual Landscape: A Reading of Mardi
}

\section{Øyvind Gulliksen}

University of Oslo

Over the years critics have assigned Herman Melville's early work, Mardi, to an inferior position in the Melville canon, and readers who have accepted Melville's invitation to "read on" have often come up with discouraging reports of feeble reward. But in spite of evident flaws, of which Melville himself was no doubt aware, Mardi deserves renewed interest, primarily because it is Melville's first fumbling attempt to combine in fictional form his previous sea experiences with his growing knowledge of religious and philosophical ideas. Reflecting on the correspondence between man, nature and metaphysics throughout Mardi, Melville contrasts a vision of man as a powerless and finite creature, with the idea of man as a superb part of a cosmic order.

In Mardi Melville reveals both his fascination and his impatience with Transcendentalism. Central to this ambivalence is the notion of a celebrated self. Eventually Melville came to see that self as being negated by the forces of nature and time, the same forces which Transcendentalists often considered supportive of their idea of selfhood.

Babbalanja, the philosopher on whom Melville comes to locus his interest in the problem of self, is introduced late. The first thirty-eight chapters center on a nameless sailor who escapes his ship and settles on an island where he is deified as a demigod called Taji. Here he starts a relationship with the mysterious Yillah, whom he has rescued from a savage priest. Upon the girl's sudden disappearance, Taji flings himself into futile pursuit of his lost love across Mardi, which becomes a metaphor for the world. He is accompanied by four new friends, among whom is Babbalanja, from then on the main character. The lost female treasure, who becomes an allegory of a vague platonic idea of beauty, is never found. 
Discussions of Mardi have centered primarily on Taji and the reactions to the lost woman, while critics have tended to neglect another approach to Babbalanja's - and Melville's - reflections on the nature of self. These reflections are complemented by some early chapters, which are often unjustly seen as extraneous to the philosophical allegory which follows. ${ }^{1}$ These chapters explore the effects of calms at sea on the nameless sailor.

In his book on Melville's heroes, Alan Lebowitz mentions the significance of the scenes of calm in Mardi as descriptions of "an existential state of living death." 2 A careful reading of the passages where calm occurs in Mardi clearly reveals how this particular phenomenon of nature serves a double function. It is not only a description of Pacific scenery, it shows the fundamental and unavoidable isolation of man. To the sailor"the stillness of the calm is awful." 3 The calm does not only leave the narrator desperately alone but also forces him into shattering self-analysis and leads to the breakdown of language and human relationship.

Chapter two, entitled "A Calm," is constructed like a poem, concentrated around a central image. The chapter consists of the narrator's recollection of what he underwent when becalmed for the first time, and "to a landsman a calm is no joke"(p.9). Rejecting the immobility of land life, the Melvillean sailor pushes out to the sea, only as in Mardi to experience another kind of calm, a frightening silence. On the silent seas, he is led to a painful and close analysis of his own existence "where existence itself seems suspended" (p. 9). In "A Calm" Melville daringly presents the going into himself to"the hollows of his very bones" (p. 10), and what he finds is not a divine everlasting soul, but possibly nothing, no innermost solid core: "He shakes himself in his coat, to see whether it be empty or no" (p. 9). In the calm, on the borders of nothingness, the solidity of the soul seems to disintegrate. The calm threatens his identity when he discovers, not without humor, that "his cranium is a dome full of reverberations" (p. 10). But these images are not used in Mardi primarily for Gothic effects; they render a feeling of existential uneasiness.

Not only is the sailor driven into the innermost of himself which he suspects exists only as a blank, if at all-but the calm threatens his belief in the existence of God. The calm "almost makes an infidel of him" (p. 9). It does not serve as a traditional demonstration of divine power; on the contrary it drives man to the borders of atheism. Once islands in the west beckoned the narrator 
as to a castle or temple (p.8), but during the experience of the calm, doubts arise as to whether land or shore exist at all. In Mardi, infinitude is far from a pleasing concept. It has the same implication as does Melville's voiceless calm, and-as Ahab and Pierre would know - there is no voice out of silence. In Mardi, the calm is doubly awful because it is both voiceless and shoreless.

The calm compels the narrator to search for an answer to the riddle of self, and the character of Jarl, the narrator's friend, is a good foil in this connection. The extraordinary obtuseness of Jarl makes him a "proper" companion to the sailor-seeker, whodesperate for communication - turns to Jarl: "I longed for something enlivening; a burst of words; human vivacity of one kind or other" (p. 36). But he meets only silence, and is again forced in upon himself where language is of no avail. In the midst of the calm, language loses meaning, speech sounds foreign, and communication collapses. Male comradeship which Melville eloquently praises in Mardi and elsewhere, now becomes unbearable. So awful is the stillness of the calm, that the narrator's voice begins to grow "strange and portentous" (p. 10).

The narrator, who has already in the first chapter compared his voyage to being in purgatory, now finds himself in a state of "'positive vacuity'; a sense of emptiness, even extinction. The sailor is locked in a position from which he cannot escape and in which even time has come to a standstill: "Vain the idea of idling out the calm.... His physical organization, obviously intended for locomotion, becomes a fixture... . He wills to go: to get away from the calm; as ashore he would avoid the plague. But he can not" (p. 10). Such a state of immobility is particularly frightening to a writer like Melville, whose feeling for movement according to Nathalia Wright was "keenest of all his sensibilities... . So keenly did he perceive this movement of life that to Melville its absence signified spiritual death." In the calm, when the motion of the ship, the wind and the waves ceases, the natural occurrence becomes an unbearable non-event, where the sailor is left like a Beckett character in the monotony of a living death.

In the calm the sailor's "thoughts of eternity thicken. He begins to feel anxious concerning his soul" (p. 10). One is reminded of what Paul Tillich calls the becoming "aware of one's possible nonbeing." The sailor grows sceptical, not so much because he is ready to proclaim the death of God, but because he faces the problem of self-affirmation when there possibly is no self. As a premonition of 
death sets in after a few days of continuous calm, the sailor realizes that "being has non-being within itself." 5 The calm as an instant of anxiety is stylistically emphasized by the use of the present tense. It is not of the past, but an intense reality of man's presence.

The symbolic application of the calm had a long tradition, of which Melville was no doubt aware. In Mardi there are some striking metaphoric and stylistic parallels to Biblical usage, but at the same time the calm in Mardi is in effect contrary to the same metaphor in the Book of Psalms, which Melville read. ${ }^{6}$ To the Psalmist the Lord "maketh the storm a calm, So that the waves thereof are still. Then they are glad because they he quiet; So he bringeth them unto their desired haven" (Ps. 107:29). There is no prevailing joy in Melville's rendering of the calm at sea. Instead of bringing the sailor to a desired haven, the calm "unsettles his mind." In all three gospels where Jesus calms the sea, the calm is an attempt to restore the uncertain faith of the disciples. Although the calm in Mardi definitely alludes to the Bible story, Melville uses the same phenomenon to symbolize the total loss of faith: "it is a calm, and he grows madly sceptical" (p. 9).

True to the New Testament original, the Puritans used the calm at sea to symbolize the perfect bliss of a Christian, whereas a severe storm gave warning or punishment. "Cotton Mather imagined heaven as a seashore "where Tides can't break thro", and in his preaching he expounded on the "Calm within" to be enjoyed after the soul had been "tossed with Tempest."' It is interesting to see Melville's use of the calm in this connection: the calm to Mather suggests spiritual safety, the same image brings the narrator of Mardi to realize a loss of the certainty of salvation. Even as Melville moves from the event to his untraditional reflection, he ironically uses a style reminiscent of the conventional sermon.

Melville surely was also aware of how important moments of calm were to the Quaker tradition. The most characteristic element of Quaker worship was the contact with God that took place in utter silence.

Among the Transcendentalists Emerson spoke of tranquillity, calm and solitude as prerequisites for a mystical union with and experience of the Over-Soul. In moments of calm, the lonesome soul was able to establish contact with the pervading life-spirit; "for the sense of being which in calm hours rises...in the soul, is not diverse from things but one with them." "Whitman spoke of a "holy calm" that "descends like dew upon me," and his companions 
were "enjoyers of calms of seas," in a sense that the narrator of early Mardi is not. ${ }^{9}$

Melville intentionally reverses this traditional imagery in order to emphasize his arguments with the tradition the imagery expressed. With contemporary Transcendentalists he pondered the wonders of an unlimited universe, but only Melville seems to have expressed how profoundly frightened he was by such a vision. Merrill Davis argues that Melville must have been aware of a debate that went on in his community at the time concerning the immensity of the universe. ${ }^{10} \mathrm{It}$ is important to notice that Melville's reflections on man's anonymous position in an overwhelming and perhaps indifferent universe, were a major drive behind his artistic efforts already at an early stage: Melville's descriptions of calms at sea with little or no hope of a safe return match the idea of man alone in a vast cosmos, in which his status is reduced to that of a "mere toy" (p. 30). His fears are vividly reflected in a sentence where he points out the dangerous position of his sailors, who by then had "drifted into the outer confines of creation" (p. 10). Being adrift or lost far out at sea is a fit image for Melville's growing metaphysical anxiety. His attempt to control this uncertainty rationally and scientifically is of little avail. In the calm the sailor grows uncertain not only about the use of geographical designations and fixed points; he doubts if they exist at all:

To his alarmed fancy, parallels and meridians became emphatically what they are merely designed as being: imaginary lines drawn round the earth's surface. ... At length horrible doubts overtake him as to the captain's competency to navigate his ship. The ignoramus must have lost his way and drifted into ... the region of everlasting lull. (pp.9-10)

Melville most probably intended the captain to be a symbol of an acting God or as God's representative as the figure of the captain was frequently used in sermons. The reference to an "everlasting lull" has significant religious overtones. But Melville has already undercut the idea of permanent peace by suggesting that the sailors are led to the lull by an "ignoramus." Only when we understand the calm, the ship, and the sea in a religious frame of reference, do we realize how daring Melville is when he suggests that the captain on board is wholly incompetent.

When the ship is becalmed a second time at the opening of chapter sixteen, there is a further illustration of Melville's tendency to reverse conventional images. This experience of a calm in the open sea might have served as a perfect setting for a Transcendental 
essay on religious union. Melville ostensibly starts on what will end in a harmonious fusion of sea and sky, man and nature-"every thing was fused into the calm: sky, air, water, and all" (p. 48) - but again he quite bluntly gives the image a surprisingly new, personal, and predominantly pessimistic tone when he goes on to say that "no vitality lurked in the air, And this inert blending and brooding of all things seemed gray chaos in conception" (p. 48). Furthermore this second calm is connected with the dark night, death, and unbearable heat. ${ }^{11}$ As earlier the calm leaves the sailors in a sense of peril, and the silence has now become "scorching." The silence of Melville's calm is physically and metaphysically uncomfortable, but it may still contain the secrets of truth. Later in Mardi Babbalanja will argue that the last wisdom is dumb and "truth is voiceless" (p. 283).

In chapter thirty-six the description of a third calm reinforces this impression: "In that hot calm, we lay all fixed and frozen in like Perry at the Pole" (p. 116). Such combinations of opposites are often used to relate an innermost mystical experience, and the Melvillean combination of heat and frost here is a familiar aspect more of hell than of heaven. The allusion to being in hell is further strengthened when the horizon is compared to "a vast serpent with ten thousand folds coiled all round the globe" (pp. 37-38).

Melville pondered the image of the calm much as he later explored the paradox of whiteness, and it is not only Yillah's whiteness that links Mardi with the predominant symbol of Mbly Whiteness commonly suggested beauty, purity and saintly robes, exactly as the calm was traditionally a symbol of the bliss in heaven, and Melville gave both motifs a different content. Even as early as in Typee Melville had joined the phenomenon of calm with whiteness. The sacred place on the island is described as having two remarkable features: it is sanctified by whiteness, the color sacred to the natives; and the place is marked by "the stillness of the grave," and a "calm solitude." 12 Here as later in Moby-Dick, Melville applied both characteristics to give a similar effect of both holiness and horror. In Moby-Dick whiteness becomes an awful non-color "a colorless, all-color of atheism," just as the calm and the corresponding blankness of the sea in Mardi convey the idea of non-existence. As white is a non-color, so all colors disappear in the calm in which the sea becomes an unreal "glassy expanse" (p. 9). In Mardi the calm is a blank, its sky overhead "colorless'j "the deep blue is gone; and the glassy element lies tranced; almost viewless as the air" (p. 48). 
There is also correspondence between the experience of a calm at sea of the nameless sailor in Mardi and of Pip in Moby-Dick. When the Mardian sailor is condemned to a calm at sea, his bravery evaporates until a wind takes him out of danger and closer to land or to a bigger ship. Pip suffers just as Mardi's sailor-seeker does in the calm. In fact, Melville prepares Pip's breakdown through statements about the calm of the sea around him: "It was a beautiful, bounteous, blue day, the spangled sea calm and cool." 13 In his study of Pip, Melville returned to the experience of what Tillich calls "the terror of ultimate loneliness." 14 The boy's experience of his own finitude in the strange and vast infinity of the sea lasts too long for him to endure, and he goes mad. To swim like Pip in a calm sea, Melville says "is as easy to the practised swimmer as to ride in a spring carriage ashore. But the awful lonesomenessis intolerable."15

Ishmael is not unaffected either by calms at sea. In a romantic moment he sees the calm as a vast prairie where "wearied children" hide after play. ${ }^{16}$ This is a blessed calm that Ishmael wishes would exist forever. But is Ishmael able to enjoy the calm of "the insular Tahiti of his own soul" once he has witnessed what the calm did to Pip? Ishmael knows that the blessed calms will not last because he will never again be able to forget the tiger heart that pants beneath the calm surface; "the profound calm which only apparently precedes and prophesies of the storm, is more awful than the storm itself; for, indeed, the calm is but the wrapper and envelope of the storm; and contains it in itself." 17

Not only whiteness but calm is also a part of Ishmael's sense of ambiguity, and both images are combined in the whale. When Ishmael exclaims, "calm, enticingly calm oh, whale thou glidest on," his statement does not only emphasize the beauty but also the mysterious voicelessness and unconquerable nature of the whale. ${ }^{18}$ Calm and white are both intricate symbols of a complex universe of beauty and horror that reduces the sailor's sense of a solid self.

The calm reoccurs in Melville's minor work although with less philosophical implications. In White Jacket the calm at sea is wedded to "int ospective ponderings," and when becalmed the sailor is often "helpless as an infant in the cradle."19 In"Benito Cereno" the calm is congruent with the tense atmosphere and the sinister plot of the story. The doldrums are a proper setting to suggest the anxiety beneath appearances. Not only has Benito Cereno repeatedly suffered from "calamitous" calms at sea, but Captain Delano's crisis takes place in a threatening calm: "The calm was confirmed. 
In the distance, away from the influence of the land, the leaden ocean seemed laid out and leaded up, its course finished, soul gone, defunct." 20

The calm, then, is a recurring motif in Melville's fiction after Mardi, and its implications, particularly in Moby-Dick, may be more fully appreciated when seen in the light of the earlier work. A greater awareness of the significance of Melville's image of the calm, however, is also of intrinsic value for an understanding of Mardi itself.

In the first part of Mardi, the sailors undergo a calm at every new stage. First there is the calm on board the whaler before they escape in a little boat only to experience a second calm. When they have gone on board a third mysterious looking ship, a third calm sets in. The devastating effects of the calm repeatedly overtake the crew. The question of becalmed nature and becalmed man is later taken up by Babbalanja, whose use of the image may offer a possible solution to the puzzling ambiguity of Mardi's ending.

To begin with, Babbalanja gives the image of calm connotations similar to those of the early chapters. The amateur philosopher musing over a heap of bones from dead kings of Mardi immediately thinks of a voiceless calm as the metaphor for being reduced to the anonymity of the grave (p. 238). About the particular calm that precedes the appearance of the dark queen Hautia, Babbalanja says that it is as effective"unto man's last despair," as it is to the serenity of the Mardian god, Oro (p. 267). The implication is that the calm has equally disastrous effects on both man and god. At the end Babbalanja unexpectedly settles in an ideal Christian community and succumbs to the teachings of the prophet Alma, who is the Christ figure of Mardi. The philosopher has been the most antagonistic questioner and doubter of all traditions and faith during the voyage, and his conversion comes as a surprise. Babbalanja, like Ishmael, survives by returning to "shore" values, whereas Taji and Ahab, heroically, but disastrously, try to realize themselves by frantic pursuit. Melville is here evidently split between a desirable conclusion which is not acceptable, continuous pursuit presented by Taji, and an acceptable conclusion which is not desirable, acceptance of a Christian Serenia represented by Babbalanja.

Babbalanja's reason for a permanent stay in Serenia is conspicuously enough the calm and tranquillity he finds there. In all Mardi, that is the world, these is "no calmer strand" (p. 623). 
Where Oro - god -is, there is an "everlasting now" (p. 620). In his final advice to Mohi, Babbalanja admonishes him to live out his life and "die calm-browed" (p. 638). According to Babbalanja the philosophy of his favorite author, Bardianna, culminated in his final words: "calmer and better" (p. 585). This would have been a perfectly reasonable motivation in a standard religious context, but Babbalanja is at this point apparently unaware of the contrary implications of the calm described in the early chapters, implications he must have seen earlier. Throughout Mardi the calm has a flavor of deathly stagnancy and formlessness, and an "everlasting calm" as a description of the godhead has become highly ambiguous and not necessarily Emerson's "great calm presence of the Creator."21 Babbalanja, then, finally accepts the symbolic values of the calm in the traditional religious sense, but the affirmation of Christian values indicated in his conversion is undercut by the use of the calm imagery earlier in the book.

The symbolism of Mardi is not integrated into full character studies nor into the narrative as a whole. But the chapters on the calm are nevertheless Melville's first serious attempt to penetrate behind appearances, to battle in Pierre's terms "on the nakedest possible plain." For the calm at sea leaves the narrator of Mardi without any suggestion of harmony between universe and soul. Indeed the experience of the calm constitutes what Merlin Bowen sees as a central theme in Melville's fiction, the experience of "self's encounter with non-self." 22

As if Melville himself was unable to live with such a dismal view, he attempts in Mardi a bold reconstruction, which, if successful, again will consolidate self with heaven. Transcendental optimism, which was seemingly rejected in the early chapters on the calm, is at intervals taken up and embraced by the meditative narrator of Mardi, whose diction and style break into passages suggestive of Whitman's. This does not mean that Melville discarded earlier sceptical statements while he was working on the later part of the book: The transition from nullification to abundance, from symbol of infinite calm and dwarfish man to super-mythical man illustrates a basic dilemma in Melville's fiction, where the conflict between an eradicated self and an everlasting self is not easily solved.

Melville's early connection with transcendental idealism is primarily recorded in a series of mythical interchapters in Mardi, which are all clearly distinguishable from the rest. ${ }^{23}$ Here the author allows himself to leave the narrative plot for a brief emphasis on an 
understanding of man through myths, a self sustainable even beyond the borders of death. With new concepts of time and creation, Melville attempts to attain a safe foundation for the nature of self. In the calm, time had come to a standstill and all activities stopped, whereas in the interchapters, mentioned above, the I-person, participating in diverse historical and mythical events, travels freely through centuries and space: "With the Israelites, I fainted in the wilderness; was in court when Solomon outdid all judges before him" (p. 297).

To understand this effort towards a reorientation of self, one must remember that both the sailor in the midst of calm and Babbalanja later had been horror stricken by the impending fact of their mortality. The narrator forms a mythic conception of self in order to get out of a merely personal dimension, which in its isolated brevity would be unbearable.

In the calm, language threatened to fall apart. In the mythical chapters, however, there is an almost ecstatic feeling of being able to create language anew. From an awful silence, the author now departs into an ample rhetoric that exalts man as nothing to man as divine. Both in Mardi and in Moby-Dick Melville constantly fluctuates between the human and the divine nature of self. A divine self is a perfect, deathless myth-self but the crucial question posed in Mardi is whether that is a true, human self.

In one of the interchapters, the narrator meditates on ancient monuments of art, primarily those that served a religious function. The Mexican House of the Sun, Solomon's temple, and the Pyramid of Cheops are all listed as symbols of significant creative effort. Melville was especially fascinated by pyramids as symbolic monuments of the life-death problem. ${ }^{24}$ Containers of secrets, they illustrated man's desire to preserve self beyond death. But not even the sanctity of temples could match the significance of literary creation. Homer's work "shall lift up its dome, when St. Peter's is a legend" (p. 229). Homer's appearance in Mardi is no coincidence. In a sense Melville did not see his Mardian voyage as a new enterprise. Me believed Mardi to have been built of old material like temples and books of antiquity. It dealt with the question of life and death that always had haunted men's minds, yet the consequences are twofold. On the one hand Mardi links with old myths, on the other hand the book indicates by strong Ecclesiastical tones that there is really nothing new to create. Behind the Homerian parallel, lurks a beginning pessimism that threatens the ambitious author-ego. 
A return to the faith that was shattered in the calm, is of little avail. Religious faith may strengthen the self "panoplied in all the armor of St. Paul," but it is delicate and easily perforated: "let us hold fast to all we have; and stop all leaks in our faith; lest an opening, but of a hand's breadth, should sink our seventy-fours" (p. 296). Here the idea recurs that faith is a frail craft as easily boarded and sunk as the boat almost was in the calm.

If the calm resulted in a standstill, the interchapters are characterized by movement as the soul in the image of a bird winds its way "into Time's endless tunnel" (p. 230). In another dream the narrator imagines himself as a ship, as symbol of movement. But dreams cannot overcome death. As Yillah becomes an unattainable dream so is the narrator's dream of himself tragically short-lived and deficient. After the flight, he hears the song of the reaper, another suggestion of death (p. 368).

The apprehension of nothingness in the calm and the reflections of all-inclusiveness in the mythical interchapters comprise the thematic contrasts between which Babbalanja attempts to reason out his conflict. Of the characters in Mardi, only Babbalanja is deeply concerned with the transitoriness of life. And Mardi's philosopher is not at all convinced that nature will offer an affirmation to the self's desire for immortality. He has discovered that nature may "promise immortality to life, but destruction to beings." Consequently he comes to the conclusion that "if not against us, nature is not for us" (p. 210). Facing a display of skeletons in a Mardian cave, Babbalanja questions immortality and sceptically asks if in "all this universal stir, am I to prove one stable thing?" (p. 238). To believe in a self beyond death would imply a preposterous elevation of that self to divine status.

Babbalanja's - and Melville's - problem is not so much with God as it is with man, man between "the godlike and the truly human," between seraph and shark, an expanded and a dwarfed I. When Babbalanja selects life in an ideal Christian community, his choice is motivated as much from fear as is Taji's pursuit. Babbalanja chooses faith, but a faith that is again unjustified by his earlier speculations and convictions. ${ }^{25}$

In Mardi Melville questions the Emersonian harmony of God, man and universe. But he allows himself to play with Transcendental premises to an extent that some critics fail to see. It is the conclusions Melville draws from those premises that are radically different from Emerson's: granted the correspondence between self 
and God, its effect on man is rather a calm fright than a calm bliss. Melville aspired in Mardi to cross chaos by contact with the transcendent, to establish a self on the Emersonian basis, to identify self with the limitless. "The soul,"Emerson said, "circumscribes all things.... In like manner it abolishes time and space." 26 Even if that be true, Melville could not be comforted. The significant mytho-poetic chapters of Mardi reflect Transcendental thought on the union of the individual with the universal self, but Melville finds a self related to such a cosmos void of positive meaning. Thus, even if the fusion were attainable, the harmony would be undesirable. The transcendental myth of self is fascinating and an inspiration to the writer, but it is basically untenable: in the end the I ends up "fixed" in a "foundationless firmament" (p. 368). Just as Melville's vision of no-self in the calm negates the traditional American-Christian solid individualism, his exploration of an allinclusive self comes to nothing. It is against this background that the final irony of Babbalanja's development must be seen. While the philosopher is led from rejection to acceptance, his transformation runs contrary to authorial use of imagery and form. Babbalanja's conversion to the calm shores of ideal Serenia thus paradoxically makes Mardi a profoundly pessimistic novel.

\section{N O T E S}

1 Henry Popkin, for instance, in his afterword to the Signet edition of Mardi (N.Y., 1904), denies any 'sign of philosophical gesture' or 'any philosophical capacity on the part of the characters' in the early part of Mardi (p. 548).

2 Alan Lebowitz, Progress into Silence: A Study of Meluille's Heroes (Bloomington, Indiana, 1970), p. 61. See also Nathalia Wright, Melville's Use of the Bible (Durham, 1949). About Maräi she says that 'the quiet water and the still air are oppressive, and the calm which pervades the scene is often a "dead calm" ' (p. 28).

3 Herman Melville, Mardi; and a Voyage Thither. Northwestern-Newberry Edition (Evanston and Chicago, 1970), p. 10. All subsequent references to Mard will be to this edition and will appear in the text.

4 Wright, pp. 27-28.

5 Paul Tillich, The Courage to Be (New Haven, 1952), pp. 35 and 34.

G Wright, p. 10.

7 Cotton Mather, Days of Humiliation, Facsimile Reproduction (Gainesville, Florida, 1970), pp. 274, 276-277. In her book American Thought and Religious Typology (New Brunswick, 1970), Ursula Brumm points out that critics have failed to see how Cotton Mather was 'read and studied by Melville' (p. 171).

8 Ralph Waldo Emerson, 'Self-Reliance:' The Complete Works of Ralph Waldo Emerson, Concord Edition (Boston and New York, 1903), II, p. 186.

9 Walt Whitman, 'The Mrstic Trumpeter' and 'Song of the Open Road,' The Complete Writings of Walt Whitman (N.Y., 1902), V, p. 250 and I, p. 64. 
10 Merrill R. Davis, Melville's Mardi: A Chartless Voyage (New Haven, 1952), p. 67.

11 There are evident echoes of Coleridge throughout the novei. The narrator's loneliness in the calm at sea, his incapacity to speak, his simile of the 'ignited coalmine' (p. 49), all run parallel to the experience of Coleridge's mariner who 'could not speak, no more than if/We had been choked with soot.' See James Dykes Campbell, ed., The Poetical Works of Samuel Taylor Coleridge (London, 1905), p. 98.

12 Herman Melville, Typee: A Peep of Polynesian Life, Northwestern-Newberry Edition (Evanston and Chicago, 1968), p. 172.

13 Herman Melville, Moby-Dick, The Standard Edition of the Works of Herman Melville (N.Y., 1963), II, p. 168.

14 Paul Tillich, The Eternal Now (S.Y., 1963), p. 19.

15 Mobv-Dick, 11, D. 169.

16 Moby-Dick, II, p. 264.

17 Moby-Dick, I, p. 357.

18 Moby-Dick, II, p. 334.

19 Herman Melville, White Jacket, The Standard Edition (N.Y., 1963), p. 409.

20 Herman Melville, The Piazza Tales, The Standard Edition (N.Y., 1963), p. 112.

21 Emerson, Complete Works, IIT, p. 28.

22 Merlin Bowen, The Long Encounter: Self and Experience in the Writings of Herman Melville (Chicago, 1960), p. 2.

23 Chapters 75, 97, 119 and 169.

24 Dorothee Metlitsky Finkelstein, Melville's Orienda (New Haven, 1961), p. 121.

25 James E. Miller Jr. regards Babbalanja as Melville's first 'maskless' hero. See his A Reader's Guide to Herman Melville (N.Y., 1962), pp. 44-45. Miller argues that Serenia is the culmination of Babbalanja's search. To support his point, he quotes Babbalanja's words, 'within our hearts is all we seek' (p.49), but Miller is evidently unaware that Babbalanja's position here may come from behind what Melville would see as a Transcendental mask, which Babbalanja in the end is unable to pierce through.

26 Emerson, Complete Works, II, p. 272.

This essay is a short version of my thesis for the cand. philol. degree from the University of Oslo 1973. I wish to express my gratitude to Prof. Sigmund Skard for his assistance and his interest in my thesis. William Beyer, Asst. Prof. Erik Kielland-Lund, and Prof. Orm $\emptyset_{\text {verland kindly read the manuscript and offered }}$ useful advice in the process of completing the essay for publication. 